\title{
Impact of phytoplankton bloom magnitude on a pelagic microbial food web
}

\author{
C. P. D. Brussaard*, G. J. Gast, F. C. van Duyl, R. Riegman \\ Netherlands Institute for Sea Research, PO Box 59, 1790 AB Den Burg, Texel, The Netherlands
}

\begin{abstract}
The impact of phytoplankton bloom magnitude on the microbial food web of the Dutch pelagic coastal zone (Southern Bight of the North Sea) was studied during spring 1993. Data were compared to a study carried out in 1992 at the same location. Light availability and temperature were the key factors for the timing of the diatom spring bloom. Specific algal cell lysis rates during the diatom bloom were always $<0.1 \mathrm{~d}^{-1}$ Due to sinking of the diatoms no effect of the difference in bloom magnitude between the 2 years on the pelagic microbial food web was detected. A high onset level of nitrate $(55 \mu \mathrm{M})$ resulted in a dense bloom of the colonial Phaeocystis, with maximum cell numbers of

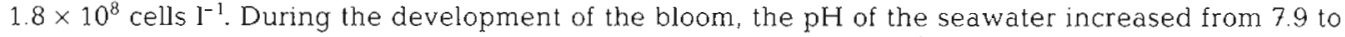
8.7. The bloom of Phaeocystis declined through cell lysis (up to $0.3 \mathrm{~d}^{-1}$ ). Due to the enhanced biomass

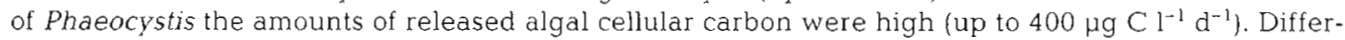
ences in Phaeocystis bloom magnitude were, as a consequence of algal cell lysis, reflected in bacterial production (up to $90 \mu \mathrm{g} \mathrm{Cl}^{-1} \mathrm{~d}^{-1}$ in 1993) and grazing activity of members of the microbial food web. The elevated importance of the microbial food web resulted in a high standing stock of microzooplankton $\left(850 \mu \mathrm{g} \mathrm{C}^{-1}\right)$ and accumulation of regenerated inorganic nutrients. Calculations on both carbon and nitrogen budgets indicate that most of the Phaeocystis bloom was mineralized within the water column.
\end{abstract}

KEY WORDS: Phytoplankton bloom magnitude - Diatoms P Phaeocystis - Cell lysis - Bacterial production - Microbial food web - Mineralization

\section{INTRODUCTION}

The occurrence of phytoplankton blooms is well known for nutrient-rich and well-mixed coastal areas (Pennock 1985, Lancelot et al. 1987, Lignell et al. 1993). Because algal blooms accumulate high amounts of organic carbon and nutrients in the particulate fraction, they are important in determining the flow of energy, carbon and organic nutrients in marine ecosystems (Holligan et al, 1984, Lignell et al. 1993, Brussaard et al. 1995). Termination of an algal bloom by sedimentation results in extensive export of particulate organic matter from the pelagic to the benthic ecosytem. Reports on the importance of sinking as a loss process frequently concern diatom blooms (Riebesell 1989, Passow 1991). In the continental coastal pelagic ecosystems in the Southern Bight of the North Sea, a

\footnotetext{
·E-mail: cpdb@nioz.nl
}

bloom of diatoms in early spring is generally followed by a bloom of the colony-forming Phaeocystis (Haptophyta, Prymnesiophyceae). Phytoplankton cell lysis following mortality appeared the most important loss factor for the Phaeocystis blooms (Van Boekel 1992, Brussaard et al. 1995). The released algal cellular carbon was the main source of carbon for bacteria (Brussaard et al. 1995). Blooming of Phaeocystis in the Dutch coastal area directed the flow of energy, carbon and organic nutrients towards the microbial food web. It can be expected that most of the photosynthetically fixed carbon will be mineralized within the microbial food web. Secondly, the release of relatively nutrientrich organic components through cell lysis will stimulate nutrient regeneration, which may affect phytoplankton succession.

Algal blooms differ in magnitude from one year to the other (Cadée \& Hegeman 1986, Lancelot et al. 1987) depending on environmental variables such as irradi- 
ance, temperature, nutrient supply, and grazing (Parsons et al. 1978, Rhee \& Gotham 1981a, b, Riegman et al. 1992, 1993, Peperzak 1993). Differences in the biomass of the algal bloom between years will be reflected in the magnitude of the loss factors and thus the energy flow. We hypothesize that the effect on the pelagic microbial food web will be most explicitly noticed whenever cell lysis is the major loss factor Variations in phytoplankton bloom magnitude will influence bacterial production, which in turn affects the grazing activity and the rate of nutrient remineralization within the microbial food web.

In this study we report on pelagic plankton dynamics in the Dutch coastal zone (Southern Bight of the North Sea) during spring 1993. To determine the impact of phytoplankton bloom magnitude (diatoms and Phaeocystis) on the microbial food web, we compare our data of 1993 with those of a field study carried out at the same location in 1992 (Brussaard et al. 1995). We furthermore describe the factors underlying the differences in algal bloom biomass.

\section{MATERIAL AND METHODS}

Samples were taken frequently during spring 1993 at high tide from the NIOZ (Netherlands Institute for Sea Research) pier in the Marsdiep tidal inlet, Texel, The Netherlands. To study algal cell lysis and plankton dynamics, a good time series is essential. The NIOZ pier allows frequent sampling without restrictions on the availability of research ships. We are, however, aware that by sampling from the NIOZ pier a proportion of the water sampled may have originated from the tidal inlets. We tried to overcome this by sampling only at high tide when the water was still incoming and therefore representative of the Dutch coastal zone. Salinities were between 28.5 and $31.5 \%$, normal values for the nutrient-enriched continental Dutch coastal area.

Reactive silicate, dissolved orthophosphate and nitrogen were analyzed by means of an autoanalyzer. Samples for total chlorophyll a (chl a) were, after gentle filtration over Whatman GF/F filters $\left(20 \times 10^{3} \mathrm{~Pa}\right)$, extracted in $90 \%$ acetone and analyzed fluorimetrically. Phytoplankton and microzooplankton were counted in buffered Lugol-preserved samples using a Zeiss inverted microscope. Phaeocystis cell numbers were converted into carbon using a factor of $12.15 \mathrm{pg}$ $C$ per flagellate cell and 14.2 pg $C$ per colonial cell (Lancelot et al. 1991). Bacterial production was estimated from incorporation rates of ${ }^{3} \mathrm{H}$-leucine $[\mathrm{L}-(4,5-$ ${ }^{3} \mathrm{H}$-leucine); 150 to $164 \mathrm{Ci} \mathrm{mmol}^{-1}$. Amershaml into bacterial protein. Aliquots of sea water (each $10 \mathrm{ml}$, made 10 nM with leucine) were incubated at field tem- perature for $1 \mathrm{~h}$, after which they were treated according to Simon \& Azam (1989). We used an intracellular isotope dilution factor of 1 , being the most conservative. Bacteria were counted on an epifluorescence microscope after collection on $0.2 \mu \mathrm{m}$ polycarbonate membrane filters (Poretics) using acridine orange. Cell numbers were converted into biomass using a factor

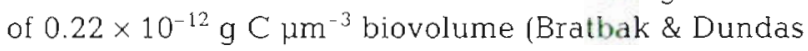
1984). Heterotrophic nanoflagellates (HNFs) were fixed with glutaraidehyde ( $1 \%$ final concentration) and, after collection on $0.2 \mu \mathrm{m}$ Nucleopore filters, stained with proflavine and counted with epifluorescence micro-

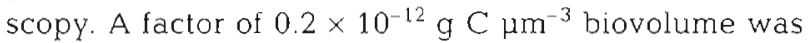
used to convert cell numbers into buomass (Fenchel 1982, Børsheim \& Bratbak 1987). Biovolume of microzooplankton was calculated from numbers per size category and converted into biomass using a factor of

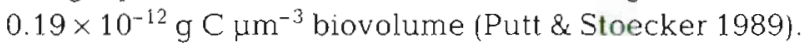
Mesozooplankton was concentrated by means of a $50 \mu \mathrm{m}$ mesh sieve, fixed with an equal volume of $4 \%$ formalin and counted under a binocular dissecting microscope. For carbon conversion factors see Brussaard et al. (1995). We used gross growth efficiencies of 0.35 for bacteria and 0.3 for heterotrophic nanoflagellates and micro- and mesozooplankton.

Specific daily phytoplankton autolysis rates were estimated based on the presence of esterase activity (EA) in the dissolved fraction of the water samples (EAD). Esterases are strictly cytoplasmatic enzymes which will be released into the water during cell leakage and can therefore be used to measure cell lysis EAD was measured fluorimetrically (Hitachi F2000 fluorometer, excitation at $451 \mathrm{~nm}$ and emission at $510 \mathrm{~nm}$ with $10 \mathrm{~nm}$ bandwidth) in triplicate at $20^{\circ} \mathrm{C}$ over $1 \mathrm{~h}$ in gently filtered field samples $(3 \mathrm{ml}$ sample over a $0.2 \mu \mathrm{m}$ Polysulfone Acrodisc syringe filter at $\left.15 \times 10^{3} \mathrm{~Pa}\right)$ using fluorescein-diacetale $(30 \mu \mathrm{l} 2 \mathrm{mM}$ FDA in $100 \%$ acetone, Sigma) as substrate and EDTA (30 $\mu 20 \mathrm{mM}$ EDTA, $\mathrm{pH}=8.0$ ) as stabilizer of FDA in sea water. Increased pressure during filtration (up to $45 \times 10^{3} \mathrm{~Pa}$ ) did not alter the results on algal cell lysis, implying that the pressure used throughout this study $\left(15 \times 10^{3} \mathrm{~Pa}\right)$ did not cause additional cell leakage. Because the $\mathrm{pH}$ of the seawater fluctuated significantly during spring (Fig. 1) we buffered the samples for the esterase assay with $8 \mathrm{mM}$ HEPES-buffer (final concentration, $\mathrm{pH}=7.9$. Aldrich). HEPES had no effect on the fluorescence signal. We assessed the stability of EAD by measuring the EA of $0.2 \mu \mathrm{m}$ filtered unbuffered seawater incubated at in situ temperature for $24 \mathrm{~h}$. Contrary to Van Boekel et al. (1992) we filtered the field samples in order to avoid lysis of algal cells present in the samples during incubation. Cell lysis of phytoplankton within the samples would have resulted in overestimated EA at the end of the 


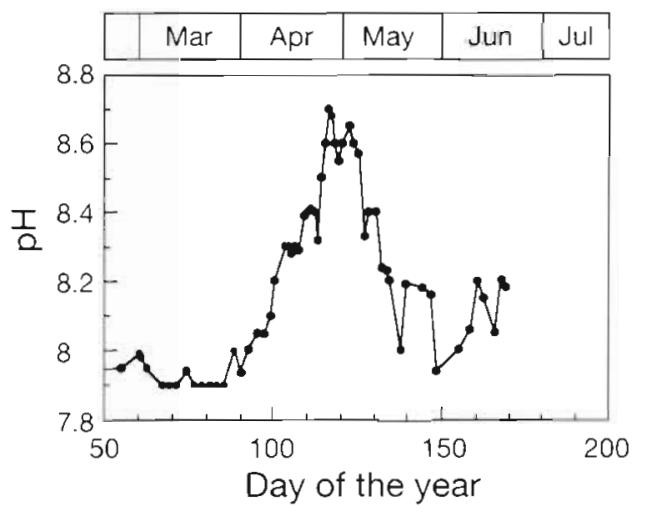

Fig. 1. Fluctuations in $\mathrm{pH}$ in the water of the Marsdiep during late winter and spring 1993

incubation and therefore in underestimated daily breakdown rates of EAD. To obtain the specific daily phytoplankton cell lysis rate, the net change of EAD over time was corrected for the dally degradation of EA and divided by the EA in the particulate algal fraction (EAP). Phytoplankton EAP could not be measured directly in the field samples due to interference by EAP from other organisms and therefore was estimated from chl a using a mean EAP to chl a ratio of $5 \pm 3 \mathrm{nmol}$ fluorescein ( $\mu \mathrm{g} \mathrm{chl} \mathrm{a})^{-1} \mathrm{~h}^{-1}$ (Brussaard et al. 1995).

\section{RESULTS}

\section{Nutrients}

Concentrations of the 4 macro-nutrients (Fig. 2) reduced strongly during late winter and early spring 1993. Silicate concentration declined to $<1 \mu \mathrm{M}$ at Day 92. At Day 109 the concentration of phosphate had dropped to $0.94 \mu \mathrm{M}$. Ammonium decreased to concentrations $<2 \mu \mathrm{M}$ at Day 85 and fluctuated between 0.73 and $2.2 \mu \mathrm{M}$ until Day 126. Nitrate concentration dropped to $1.2 \mu \mathrm{M}$ on Day 125. Ammonium, phosphate and nitrate levels peaked again during a 3 wk period between Days 140 and 160. Ammonium reached a maximum value of $21 \mu \mathrm{M}$ on Day 155.

\section{Phytoplankton}

The maximum concentration of diatom cells (Fig. 3A) was found on Day $88\left(2.3 \times 10^{6} \mathrm{l}^{-1}\right)$. Phaeocystis was abundant from Days 100 to 170 (Fig. 3B), during which the major blooming period was found from Days 100 to 134. Highest numbers of Phaeocystis colonies of 5-8 $\times 10^{4} \mathrm{I}^{-1}$ were counted between Days 107 and 118 .
Phaeocystis total cells reached maximum numbers of $1.8 \times 10^{8} \mathrm{l}^{-1}$ on Day 119. Phaeocystis flagellate cell numbers were very low $\left(<0.4 \times 10^{7} \mathrm{l}^{-1}\right)$ until Day 116 . Whereas Phaeocystis colonial cell numbers were already declining (since Day 119), flagellate cell number still increased until Day 123. The bloom of Phaeocystis is reflected in the chl a concentration (Fig. 3C). The high production of Phaeocystis biomass coincided with an increase in $\mathrm{pH}$ (Fig. 1) up to 8.7 at the peak of the bloom.
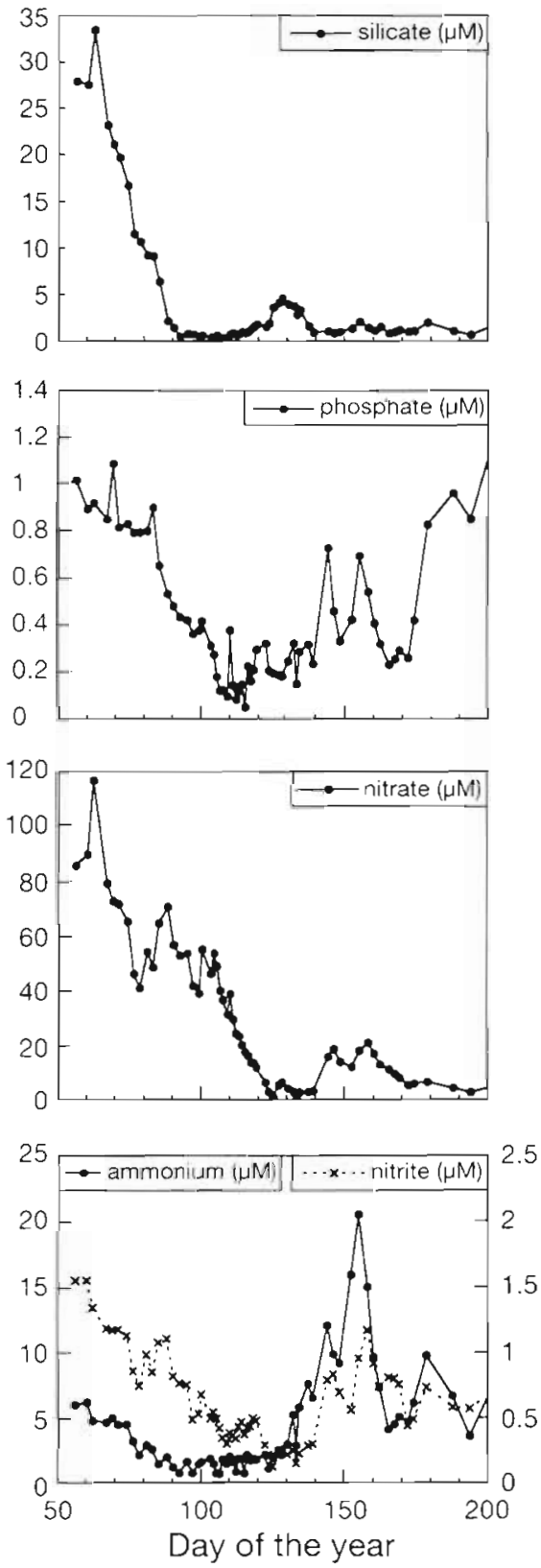

Fig. 2. Variations in the concentrations of silicate, phosphate, nitrate, ammonum and nitrite $(\mu M)$ in the water of the Marsdiep during 1993 

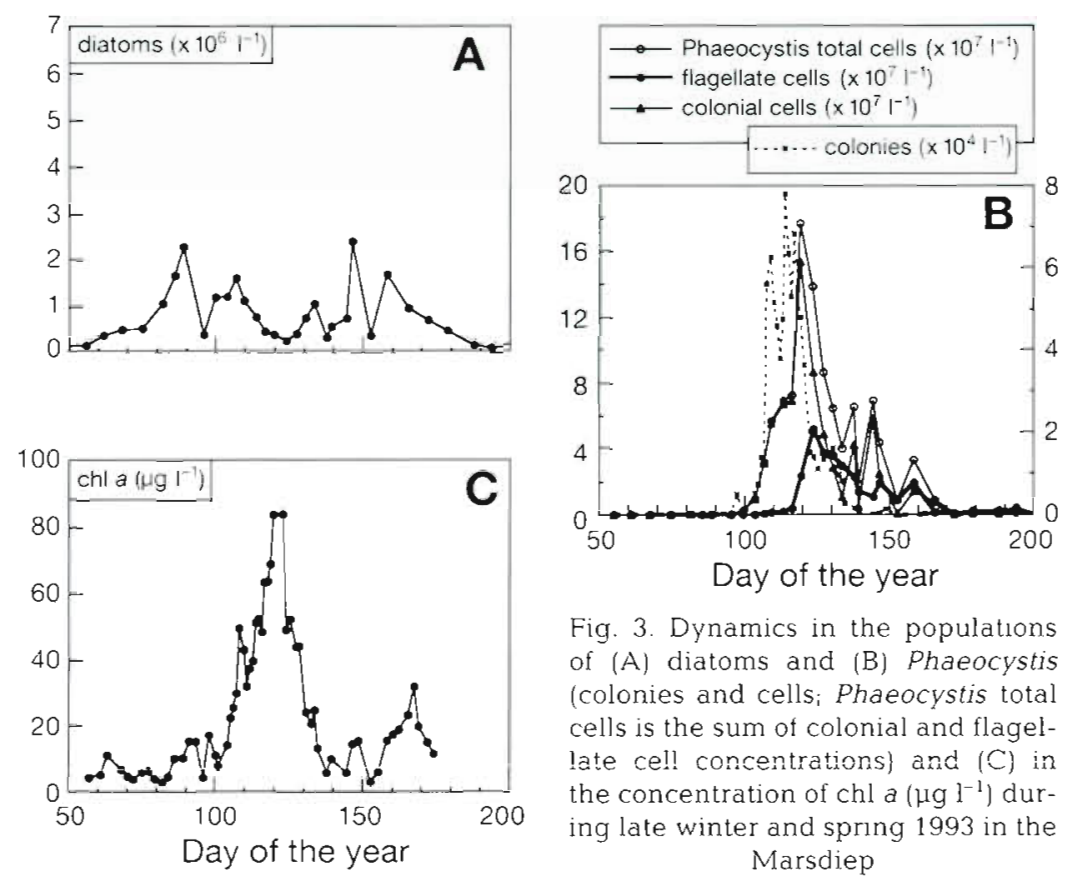

Fig. 3. Dynamics in the populations of (A) diatoms and (B) Phaeocystis (colonies and cells; Phaeocystis total cells is the sum of colonial and flagellate cel! concentrations and (C) in

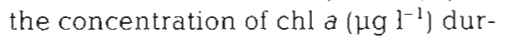
ing late winter and spring 1993 in the Marsdiep

the stability of EAD in the field samples and the $\mathrm{pH}$ in the ambient water (within the range of 7.9 to 8.7 ) was found. Using sonificated cultures of the diatom Skeletonema costatum, we found the rates of EA degradation independent of $\mathrm{pH}$. Neither temperature $\left(3.5\right.$ to $\left.20^{\circ} \mathrm{C}\right)$ nor bacteria affected the stability of EA in sonificated cultures of Phaeocystis. Compared to the lysis rates based on an EA degradation rate of $25 \% \mathrm{~d}^{-1}$ (Brussaard et al. 1995), the algal lysis rates in this study were higher (on average $1.6 \pm 0.5$ times, $n=$ 15) due to the lower stability of EAD The higher daily breakdown rates resulted in higher amounts of released EA over time and thus in higher specific cell lysis rates, as is illustrated in Fig $4 \mathrm{~B}$. Because of the large variation in the stability of EA, we were unable to correct the majority of data on algal cell lysis for which no in situ degrada-

Phytoplankton cell lysis

During the diatom spring bloom, the specific daily algal cell lysis rates (Fig. $4_{i}$ expressed as percentage of EAP released daily) were always less than $10 \% \mathrm{~d}^{-1}$. Highest lysis rates (up to $33 \% \mathrm{~d}^{-1}$ ) were observed during Phaeocystis dominance, and corresponded to either reduced increases or decreases in phacocystis colonial cell number.

In order to correct for the $\mathrm{pH}$ in the field, HEPESbuffer was added to the samples during the esterase assay. Specific daily lysis rates obtained from samples incubated with HEPES buffer were in general lower $(12 \pm 20 \%$ lower, $n=54)$ than the lysis rates derived without the addition of HEPES (Fig. 4A).

The in situ degradation rates of EAD ranged between 29 and $59 \% \mathrm{~d}^{-1}$, with an average rate of $43 \pm$ $11 \% \mathrm{~d}^{-1}(\mathrm{n}=15)$. No significant relationship between tion rates were obtained. To compare the data with a study executed in 1992 (Brussaard et al. 1995), we used lysis rates based on a daily EA degradation rate of $25 \%$ to calculate the amounts of released cellular carbon released. However, for future studies we recommend the estimation of EA stability for every sample.

At the peak of the bloom, when the algal biomass consisted mainly of Phaeocystis, the ratio of Phaeocystis cellular $\mathrm{C}$ to chl a was $29( \pm 8.5, \mathrm{n}=5)$. This value is equal to those commonly reported for Phaeocystis (Lancelot et al. 1991, Davies et al. 1992) and was used to calculate the amounts of algal cellular carbon released daily (Fig. 5). The release of algal cellular carbon during the diatom bloom was below $10 \mu \mathrm{g} \mathrm{Cl}^{-1} \mathrm{~d}^{-1}$ Due to the high rates of algal cell lysis and the high biomass of Phaeocystis, most algal cellular carbon was released during the bloom of Phaeocystis (up to almost $400 \mu \mathrm{g} \mathrm{C} \mathrm{l}^{-1} \mathrm{~d}^{-1}$ ).

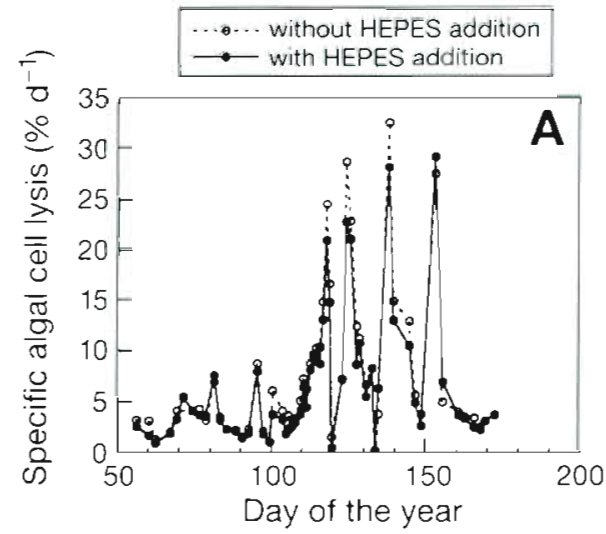

Fig. 4. Fluctuations in the level of specific daily phytoplankton cell lysis $[\%$ esterase activity (EA) in the particulate algal fraction released per day] in the water of the Marsdiep during spring 1993. (A) Algal cell lysis with and without additıon of HEPES-buffer using an EA breakdown rate of $25 \% \mathrm{~d}^{-1}$, and $(B)$ algal lysis rates estimated in the samples with HEPES addition using a fixed EA degradation rate of $25 \% \mathrm{~d}^{-1}$ or variable rates estimated in situ 


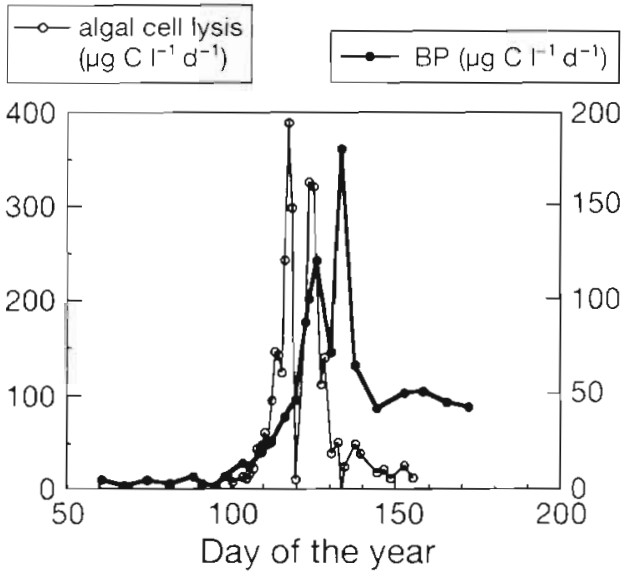

Fig. 5. Variations in the amount of algal cellular carbon released daily by phytoplankton cell lysis $\left(\mu \mathrm{g} C\right.$ released $\left.\mathrm{l}^{-1} \mathrm{~d}^{-1}\right)$. and bacterial production (BP, $\mu g \mathrm{C}^{-1} \mathrm{~d}^{-1}$ ) in the Marsdiep during spring 1993

\section{Bacterial production and biomass}

For 1993, as well as for 2 other years (van Duyl unpubl.), bacterial production was significantly related to temperature as long as the Phaeocystis bloom did not decline (Fig. 6; $r<0.9$ and $p<0.001$ for the slope, using ANOVA).

During the early spring diatom bloom bacterial production was below $5 \mu \mathrm{g} \mathrm{C} \mathrm{l}^{-1} \mathrm{~d}^{-1}$ (Fig. 5). Bacterial production followed the released algal cellular carbon during the bloom of Phaeocystis, and reached rates up to $90 \mu \mathrm{g} \mathrm{C}^{-1} \mathrm{~d}^{-1}$ (Day 134). After the bloom collapsed, bacterial production stayed on a higher level than before the bloom (around $25 \mu \mathrm{g} \mathrm{Cl}^{-1} \mathrm{~d}^{-1}$ ).

Bacterial biomass increased with bacterial production and peaked on Day 133 (311 $\mathrm{gg} \mathrm{Cl}^{-1}$, Fig. 7A). A second peak in bacterial biomass was observed on Day 165 (279 $\mu \mathrm{g} \mathrm{C}^{-1}$ ), during which the bacterial production was constant.

\section{Zooplankton biomass}

Heterotrophic nanoflagellates (Fig. 7A) showed a comparable trend in biomass to the bacteria. The first peak

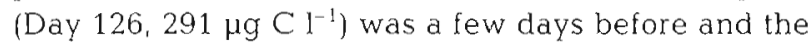
second (Day 172, $287 \mu \mathrm{g} \mathrm{Cl}^{-1}$ ) just after peaks in bacterial biomass. Before Day 126, small $(<5 \mu \mathrm{m}$ ) HNFs dominated in cell number, whereas thereafter no dominance in cell number of the small or larger HNFs was found.

Microzooplankton (Fig. 7B) consisted of 2 groups: tintinnid ciliates and other microzooplankton (predominantly oligotrichous ciliates). Tintinnids became significant after Day 130 and caused the high peak in

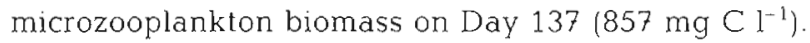
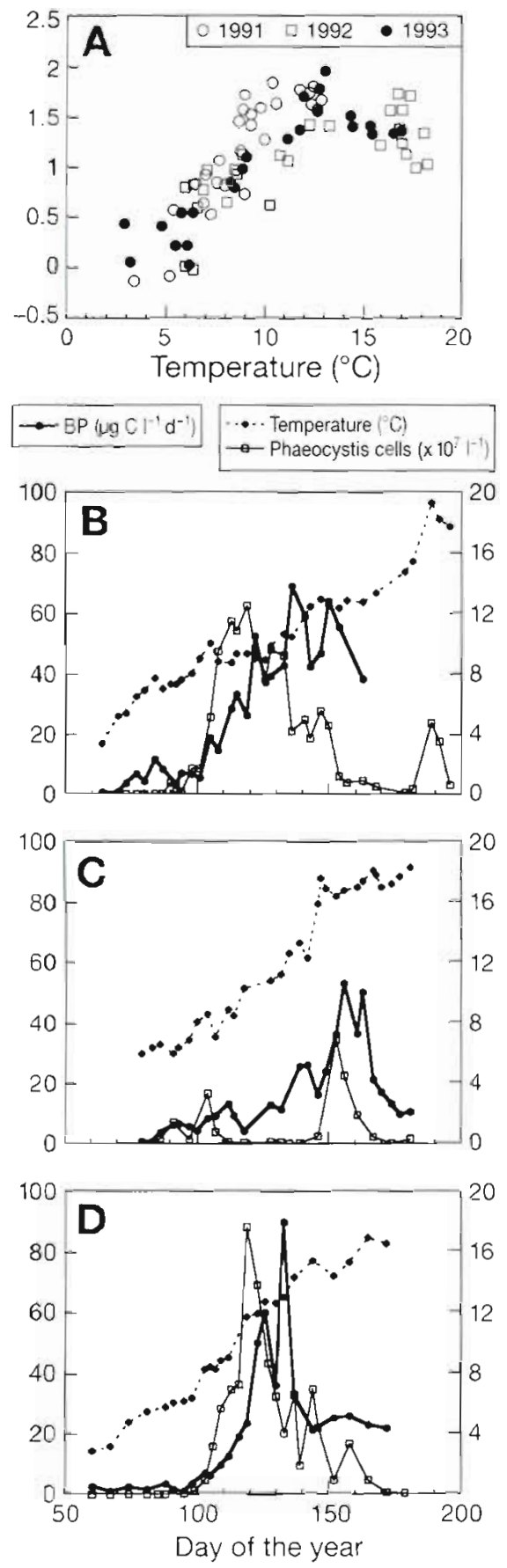

Fig. 6. (A) Log bacterial production (log BP) versus temperature for the years 1991, 1992, and 1993. Dynamics of BP ( $\mu \mathrm{g} \mathrm{C}$ $\left.\mathrm{I}^{-1} \mathrm{~d}^{1}\right)$, Phaeocystis cell concentration $\left(\times 10^{7} 1^{-1}\right)$, and temperature $\left({ }^{\circ} \mathrm{C}\right.$ ) for (B) 1991, (C) 1992, and (D) 1993

Naked ciliates peaked on Day $116\left(498 \mu \mathrm{g} \mathrm{Cl}^{-1}\right.$ ), and declined afterwards to $<50 \mu \mathrm{C} \mathrm{Cl}^{-1}$ on Day 144 .

Mesozooplankton biomass (Fig. 7B) peaked on Day $130\left(157 \mu \mathrm{g} \mathrm{C} \mathrm{I}^{-1}\right)$, which was $2 \mathrm{wk}$ after the peak in naked oligotrichous ciliates. A second peak occurred on Day 158 (313 $\mu \mathrm{g} \mathrm{C}^{-1}$ ) 3 wk after the 


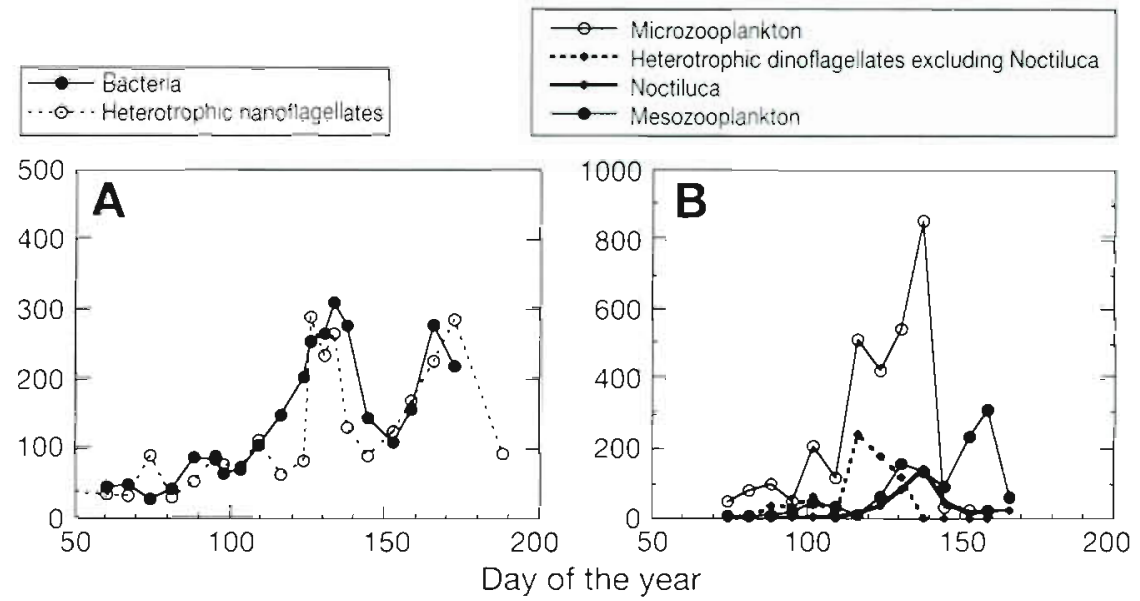

Fig. 7. Dynamics in biomass ( $\mu \mathrm{C}^{-1}$ ) of (A) bacteria and heterotrophic nanoflagellates and (B) of microzooplankton, Noctiluca millarss, heterotrophic dinoflagellates other than $N$ miliaris, and mesozooplankton during 1993 in the Marsdiep area. Note the different scales in (A) and (B) peak in tintinnid biomass. Mesozooplankton consisted mainly of copepods, with the share of adult copepods increasing in time.

The heterotrophic dinoflagellate Noctiluca miliaris (Fig. 7B) peaked once on Day 137 and reached a maximum biomass of $143 \mu \mathrm{g} \mathrm{Cl}^{-1}$. Heterotrophic dinoflagellates other than $N$. miliaris were significantly present from Days 88 to 130 , with a maximum biomass of $243 \mu \mathrm{g} \mathrm{C} 1^{-1}$ on Day 116 (Fig. 7B).

\section{DISCUSSION}

\section{Diatom bloom}

The onset of the diatom bloom in early spring was delayed and the increase in biomass less rapid compared to 1992 (Brussaard et al. 1995). Light availability and temperature influence the growth of phytoplankton (Yoder 1979, Rhee \& Gotham 1981a, b). Compared to other years we found a low mean water-column radiation $\left(<22 \mathrm{Wh} \mathrm{m}^{-2} \mathrm{~d}^{-1}\right.$, estimated according to Peperzak 1993 and Brussaard et al. 1995) from Days 40 to 56 , which was due to low solar radiation $1<200 \mathrm{~J}$ $\mathrm{cm}^{-2} \mathrm{~d}^{-1}$ ). From Days 55 to 70 , temperature was relatively low $\left(<4^{\circ} \mathrm{C}\right)$. Low radiation, accompanied by low temperatures delayed the onset of the diatom bloom. Size-selective grazing (Riegman et al. 1993) may explain the sharp decline in silicate concentration from Day 60 without an accompanying increase in phytoplankton biomass during the next 2 wk. With maximum diatom cell concentrations half those in 1992, a comparable species composition (G. C. Cadée pers. comm.) and a stronger decline in silicate concentration, the diatom bloom must have been the result of higher loss rates. Grazing by mesozooplankton was unlikely due to its low standing stock in early spring. and low numerical response at the prevailing tempera- tures (Klein Breteler et al. 1982). Diatom cell lysis appeared to be a loss fartor of only minor importance $\left(<0.1 \mathrm{~d}^{-1}\right)$. Sedimentation very likely controlled the height of the diatom standing stock (Moloney et al. 1986). Passow (1991) found species-specific aggregation to be responsible for a rapid differential disappearance of diatom species blooming during spring. As the amounts of algal cellular components released by lysis were low $\left(<10 \mu \mathrm{g} \mathrm{C} \mathrm{l}^{-1} \mathrm{~d}^{-1}\right)$ and most of the particulate matter was lost from the pelagic ecosystem by sedimentation, pelagic bacteria showed no response to the diatom bloom.

With bacterial production being half that of 1992, differences in diatom bloom biomass between the 2 years were reflected in bacterial production. However, the impact on the microbial food web is negligible because of the low bacterial production rate.

\section{Phaeocystis bloom}

As long as the concentration of silicate is above $2 \mu \mathrm{M}$, Phaeocystis loses the competition for both nitrogen and phosphate from diatoms (Egge \& Aksnes 1992). At the time silicate became depleted, mean water-column photosynthetically active radiation was about $200 \mathrm{Wh}$ $\mathrm{m}^{-2} \mathrm{~d}^{-1}$, which is well above the threshold level for colony formation (100 $\mathrm{Wh} \mathrm{m}^{-2} \mathrm{~d}^{-1}$, Peperzak 1993) and therefore did not prevent the blooming of Phaeocystis colonies as it did in 1992 (Brussaard et al. 1995). The higher levels of nitrate at the start of the bloom in 1993 (55 $\mu \mathrm{m}$ compared to $20 \mu \mathrm{M}$ in 1992) allowed Phaeocystis to reach higher cell numbers ( $~ 3$ times higher than in 1992). This is in good agreement with the recently reported significant relationship between the nitrate concentrations at the onset of a Phaeocystis bloom and the cell density at the top of the bloom (Lancelot 1995). During the build-up of the Phaeocystis 
bloom, pH increased from 7.9 to 8.7 as a result of $\mathrm{CO}_{2}$ net fixation into the alga. Apparently, $\mathrm{CO}_{2}$ uptake could not be balanced by diffusion from surrounding waters or the atmosphere during the increase in Phaeocystis biomass. Comparable $\mathrm{CO}_{2}$ dynamics has been reported for the lower part of the Narraganset Bay (Hinga 1992).

A decline in Phaeocystis colony number, and the occurrence of 'ghost' colonies (Verity et al. 1988) only 1 wk after the bloom started can be explained by a dip in mean water column radiation from Days 106 to 109 to levels below $100 \mathrm{Wh} \mathrm{m}^{-2} \mathrm{~d}^{-1}$. Despite high solar radiation ( $>5000 \mathrm{Wh} \mathrm{m}^{-2} \mathrm{~d}^{-1}$, data supplied by Royal Dutch Meterological Institutel Phaeocystis probably also experienced light limited growth during the period of bloom decline (Days 119 to 134) due to self-shading, as was reflected in a strong decline in secchi disk values (G. C. Cadée pers. comm.). Our data suggest that beside potential light limitation, the Phaeocystis bloom became depleted by nitrate $\left(K_{\mathrm{s}}=4 \mu \mathrm{M}\right.$ for inorganic nitrogen, Lancelot et al. 1986). The formation rate of colonies is reduced when there is low availability of nitrate (Riegman et al. 1992). The number of colonies declined due to desintegration of the colony matrix, whereas the decline in colonial cell number was caused by cell lysis and transformation into flagellate cells by the rest of the colonial cells. A rise in number of flagellate cells during the decline of colonial cells was observed in our study. The increasing concentration of ammonium recorded at the end of the bloom prevented the formation of new colonies even more (Riegman et al. 1992). Ammonium inhibited the uptake of nitrate (McCarthy et al. 1975), whereas low light may have negatively influenced the reduction of nitrate to ammonium within the algal cells (Syrett 1981). The high $\mathrm{pH}$ in the ambient water during the Phaeocystis bloom (up to 8.7) probably also affected the development of the bloom. Photosynthesis induces not only a rise in external $\mathrm{pH}$, but also inside Phaeocystis colonies high values of $\mathrm{pH}$ have been reported (up to 9. Lubbers et al. 1990). This may have restricted the rate of primary production in Phaeocystis (Riebesell et al. 1993) and the nitrogen metabolism within the cells. We found no significant relationship between specific algal cell lysis and $\mathrm{pH}$ during the bloom of Phaeocystis. We hypothesize that as a result of nitrogen and energy deficiency, synthesis of structural and functional components was blocked which resulted in osmolytic deregulation and subsequently cell death through plasmolysis.

Although viruses can also be potential mortality agents for algal blooms (Bratbak et al. 1993, Brussaard et al. 1996), the complete absence of any viral infection within cells of Phaeocystis sampled at different stages of the bloom during spring 1994 (authors' unpubl. results) indicate that viruses may at least not always be important for the decline of Phaeocystis blooms in the Dutch coastal area.

The decline of the major peak in Phaeocystis colonial

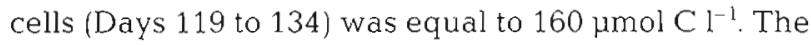
integrated release of algal cellular carbon due to cell

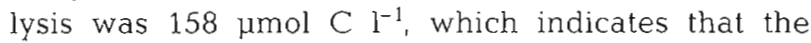
Phaeocystis bloom declined through cell lysis. Released algal cellular carbon was 2.9 times higher than was estimated during the Phaeocystis bloom in 1992 (cell lysis recalculated using a C:chl a ratio of 29), reflecting a comparable enhancement of Phaeocystis biomass.

Based on carbon standing stock we calculated the net variation of the population of heterotrophs (the sum of bacteria, HNFs, microzooplankton, heterotrophic dinoflagellates, and mesozooplankton) over this period. The heterotrophic carbon demand (estimated from net production and a gross growth efficiency of 0.3 ) was $167 \mu$ mol $\mathrm{C} \mathrm{I}^{-1}$. The close match with the losses of Phaeocystis suggest that the bloom of Phaeocystis was mineralized within the water column. We are aware that this conclusion largely depends on the conversion factors used. The conversion factors yielding Phaeocystis cellular carbon were based on cell concentrations and had standard deviations of $35 \%$ (Lancelot et al. 1991). Applying these to our data still resulted in $78 \%$ of the Phaeocystis bloom being mineralized within the water column. Our data on the stability of EAD indicated that the actual specific algal cell lysis rates, and thus the amount of released algal cellular carbon, were probably higher (on average 1.6 times). On the other hand, the ratio of EAP to chl $a$ in senescent colonycontaining cultures of Phaeocystis (comparable to the decline of the bloom in the field) was found to be up to 2 -fold higher than the mean ratio of 5 used in this study. The consequently 2 -fold lower algal lysis rates will compensate for the positive effect of the lower stability of EAD on algal cell lysis. The extracellular polysaccharides of the Phaeocystis colony mucus were thought to be largely resistant to biodegradation (Thingstad \& Billen 1994, Lancelot 1995) and were therefore not included in the $C$ budget calculated for Days 119 to 134 .

From Days 134 to 170 , cell lysis was not the only loss factor responsible for the declines in Phaeacystis cell

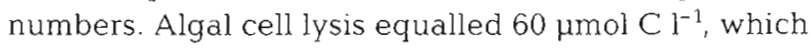
was only $40 \%$ of the cumulative losses of Phaeocystis during this period. The rates of losses other than cell lysis were estimated by taking the net result of specific algal cell lysis and specific net growth rate of Phaeocystis, and were between 0.1 and $0.4 \mathrm{~d}^{-1}$. Since sinking of Phaeocystis seems to be not important in the turbulent Dutch coastal area (Van Boekel et al. 1992, Brus- 
saard et al. 1995), these rates most probably indicated grazing pressure. It is very likely that the tintinnids grazed on the fast growing Phaeocystis flagellate cells. Grazing on Phaeocystis single cells by tintinnids has been observed by Admiraal \& Venekamp (1986). The succession of naked ciliates by tintinnids can be explained by the size of Phaeocystis cells ( 3 to $8 \mu \mathrm{m}$ ). Tintinnids consume most actively nanoplankton in the size range 3 to $10 \mu \mathrm{m}$ (Rassoulzadegan et al. 1988), whereas oligotrichs feed most efficiently on prey in the $2.5 \mu \mathrm{m}$ size range (Bernard \& Rassoulzadegan 1990).

\section{Microbial food web}

At low substrate concentrations, pronounced effects of temperature on bacterial growth are reported (Pomeroy et al. 1991). Such conditions applied in the Dutch coastal zone in early spring when diatoms dominated the algal biomass. At higher substrate concentrations temperature was shown to have little effect on bacterial growth and respiration (Pomeroy \& Wiebe 1993). The relatively high amounts of algal cellular components released through cell lysis during the Phaeocystis bloom masked the relationship between bacterial production and temperature.

During the major part of the bloom (Days 100 to 134), the cellular carbon released by Phaeorystis due to cell lysis was equal to $305 \mu \mathrm{mol} \mathrm{C} \mathrm{^{-1 }}$, sufficient to account for the bacterial carbon demand of $240 \mu \mathrm{g} \mathrm{C}^{-1}$ during this period. After Day 140, the bacterial carbon demand was higher than could be sustained by algal cell lysis. It is likely that additional food sources such as byproducts of animal ingestion and digestion (Jumars et al. 1989) and the large amount of slowly biodegradable extracellular polysaccharides of the Phaeocystis colony mucus (Thingstad \& Billen 1994) supplied the bacteria with carbon.

The enhanced amounts of released algal cellular carbon compared to 1992 were reflected in bacterial production (2.3 times higher). Enhanced bacterial production following a relatively large bloom of Phaeocystis was also found for 1991 (Fig. 6), suggesting a general validity of the coupling of bacterial production to the magnitude of the Phaeocystis bloom owing to lysis of Phaeocystis cells.

The enhanced bacterial production rates were not reflected in bacterial biomass implying higher loss rates (mortality rates up to $0.28 \mathrm{~d}^{-1}$ compared to maximum rates of $0.1 \mathrm{~d}^{-1}$ in 1992). Though grazing by HNFs (Weisse 1990) seemed responsible for the mortality of bacteria, viral lysis of bacteria cannot be ruled out as a potential loss factor (Proctor et al. 1993). The rise in biomass of HNFs (Days 116 to 126 ) coincided with the decline in biomass of naked oligotrichous ciliates, suggesting that HNFs were controlled by grazing of microzooplankton (Weisse 1990) Heterotrophic dinoflagellates are not very selective for prey type (Hansen 1992) and probably competed with ciliates for prey. Unlike heterotrophic dinoflagellates, HNFs (Fenchel 1982) and microzooplankton (Verity 1986), mesozooplankton cannot respond very fast to an increase of prey (Klein Breteler et al. 1982). This allows the prey of mesoozooplankton to reach high biomasses. Differences in Phaeocystis bloom magnitude between the 2 years under study were, as a consequence of algal cell lysis and bacterial production, reflected in the standing stock of microzooplankton.

The high grazing activity on all trophic levels of the microbial food web resulted in substantial accumulation of regenerated inorganic nutrients, especially ammonium. It has already been known for a long time that mesozooplankton excrete both nitrogen and phosphorus (Ikeda 1977) Only in the last decade has it become more clear that Protozoa have to be considered as the more important mineralizers of nutrients, as is clearly illustrated by the computer simulation model of Moloney et al. (1986). Verity (1985) reported high excretion rates of ammonium by tintinnids, which are thought to be typical for temperate coastal waters. Ageing cells of Noctiluca miliaris rise to the water's surface and release, due to cell lysis, ammonium and phosphate (Schaumann et al. 1988). Although depending on the $\mathrm{C}: \mathrm{N}: \mathrm{P}$ ratio of the algal lysis components (Caron et al. 1988, Jürgens \& Güde 1990), it is likely that bacteria also contributed to the excretion of ammonium and phosphorus as they were found to be carbon limited during this study.

Calculations on the nitrogen budget (Table 1) show that the shift in biomass composition between Days 119 and 155 was equivalent to a decrease of $27 \mu \mathrm{mol} \mathrm{N} l^{-1}$ Correction of the in situ concentrations of ammonium, nitrate and nitrite for conservative mixing of fresh water (IJsselmeer, $\mathrm{S} \approx 0.3 \%$ ) and offshore North Sea water $(S \approx 33.5 \%)$ end members resulted during this period in a net accumulation of $29 \mu \mathrm{mol} N$ $\mathrm{l}^{-1}$ (maximum concentration on Day 155). The strongest. incline in the concentration of inorganic nitrogen was found after the major decline of the Phaeocystis bloom (Days 119 to 134), during which the net variation of the heterotrophic nitrogen became negative. Ammonium and nitrate are released from the sediments in the Dutch coastal. waters at rates of approximately 12 and $5 \mathrm{mg} \mathrm{N} \mathrm{m} \mathrm{m}^{-1}$, respectively (Billen et al. 1990). Between Days 119 and 155 this would have resulted theoretically in an accumulation of only $2 \mu \mathrm{M}$ ammonium and $1 \mu \mathrm{M}$ nitrate. Not only most of the remineralization of ammonium, but also most of the nitrification took place within the water column. The 
Table 1 Nitrogen standing stocks ( $\mu \mathrm{mol} \mathrm{N} \mathrm{l}^{-1}$ ) of the populations of Phaeocystis, bacteria, HNFs, microzooplankton, het erotrophic dinoflagellates (HD, excluding Noctiluca miliaris). $N$ miliaris, mesozooplankton, and the concentration of ammonium $(\mu \mathrm{M})$ in the Marsdiep area on Days 120, 134 and 155. Total heterotrophic biomass is the sum of bacteria, HNFs, microzooplankton, heterotrophic dinoflagellates, and mesozooplankton. Nitrogen was calculated from carbon biomass using a $\mathrm{C}: \mathrm{N}$ ratio of 10 for Phaeocysts and 4 for heterotrophs. Concentrations of the considered nitrogen compound after correction for conservatuve mixing are given in parentheses. This was done by subtracting the fraction determined by conservative mixing of coastal North Sea water and IJsselmeer water from the in situ concentration

\begin{tabular}{|c|c|c|c|}
\hline Day. & 119 & 134 & 155 \\
\hline & \multicolumn{3}{|c|}{ Particulate organic $N(\mu M)$} \\
\hline Phaeocystis & 20.5 & 4.6 & 2.0 \\
\hline Bacteria & 3.5 & 6.4 & 2.7 \\
\hline HNFs & 1.5 & 5.4 & 3.0 \\
\hline Microzooplankton & 9.8 & 14.9 & 0.6 \\
\hline HD & 4.5 & 1.1 & 0 \\
\hline Noctiluca milians & 0.7 & 2.5 & 0.6 \\
\hline Mesozooplankton & 0.8 & 3.2 & 5.8 \\
\hline \multirow[t]{2}{*}{ Total for heterotrophs } & 20.8 & 33.5 & 12.7 \\
\hline & \multicolumn{3}{|c|}{ Dissolved inorganic $N(\mu \mathrm{M})$} \\
\hline Ammonium & $1.8(0.9)$ & $4.5(3.6)$ & $20.3(16.7)$ \\
\hline Nitrate & $12.4(1.1)$ & $2.2(-3.0)$ & $17.7(13.8)$ \\
\hline Nitrite & $0.5(0.3)$ & $0.2(0)$ & $0.9(0.7)$ \\
\hline Total nitrogen saits & $14.7(2.3)$ & $6.9(0.6)$ & $38.9(31.2)$ \\
\hline
\end{tabular}

potential importance of nitrification in coastal marine ecosystems has been reported also by Berounsky \& Nixon (1985). The actual concentration of regenerated ammonium would have been higher because growth of diatoms at the end of this period had lowered the actual concentration of regenerated ammonium. In conclusion, not only the calculations based on the carbon but also on the nitrogen budget clearly indicate that the major part, if not all, of the Phaeocystis bloom was mineralized within the water column. As stated by Wassmann (1994), mineralization within the water column of most of the Phaeocystis bloom can be expected in areas like the Dutch coastal zone with high turbulence energy supply.

Summarizing, the hypothesis that phytoplankton bloom magnitude affects the importance of the microbial food web in the Dutch coastal pelagic ecosystem whenever algal cell lysis is the major loss factor was confirmed by the blooming of Phaeocystis. An enhanced bloom of the colonial Phaeocystis could have developed in spring 1993 due to a high standing stock of nitrate at the onset of the bloom. Cell lysis was the major loss factor for the Phaeocystis bloom and the large amount of released cellular components resulted in enhanced bacterial production. Elevated grazing activity by members of the microbial food web and the relatively low numerical response by mesozooplankton explained why only microzooplankton biomass was affected by variation in Phaeocystis bloom magnitude. In contrast to the preceeding diatom bloom, most of the Phaeocystis bloom was mineralized within the water column. The utilization of the high concentration of released nutrient-rich algal organic matter by heterotrophs led to substantial accumulations of regenerated inorganic nutrients.

Acknowledgements. We are indebted to Drs G. Cadée and R. Bak for providing data on Phaeocystus cell numbers and heterotrophic nanoflagellates, respectively. We arc grateful to Harry Witte for counting zooplankton and to Karel l3akker for nutrient analyses. Thanks to Gerard Nieuwland, Arjen Kop and Anna Noordeloos for their assistance. Monitory data on nutrients in the IJsselmeer and North Sea were kindly provided by the National Institute for Coastal and Marine Management (RIKZ). This study was executed within the EC framework programme STEP (contract no. STEP-CT900062 ), and is NIOZ publication 3089.

\section{LITERATURE CITED}

Admiraal W, Venekamp LAH (1986) Significance of tintinnid grazing during blooms of Phaeocystis pouchetii (Haptophyceae) in Dutch coastal waters. Neth J Sea Res 20(1): $61-66$

Bernard C, Rassoulzadegan F (1990) Bacteria or microflagellates as a major food source for marine ciliates: possible implications for the microzooplankton. Mar Ecol Prog Ser 64:147-155

Berounsky VM, Nixon SW (1985) Eutrophication and the rate of net nitrification in a coastal marine ecosystem. Estuar Coast Shelf Sci 20:773-781

Billen G, Joiris C, Meyer-Rell L, Lindeboom H (1990) Role of bacteria in the North Sea ecosystem. Neth $\mathrm{J}$ Sea Res 26(2-4):265-293

Borsheim KY, Bratbak G (1987) Cell volume to cell carbon conversion factors for a bacterivorous Monas sp. enriched from seawater. Mar Ecol Prog Ser 36:171-175

Bratbak G, Dundas ] (1984) Bacterial dry matter content and biomass estimations. Appl Environ Microbiol 48(4):755-757

Bratbak G, Egge JK, Heldal M (1993) Viral mortality of the marine alga Emiliania huxleyi (Haptophyceae) and termination of algal blooms. Mar Ecol Prog Ser 93:39-48

Brussaard CPD, Kempers RS, Kop A.J, Riegman R, Heldal M (1996) Virus-like particles in a summer bloom of Emiliania huxleyi in the North Sea. Aquat Microb Ecol 10:105-113

Brussaard CPD, Riegman R, Noordeloos AAM, Cadée GC, Witte $H$, Kop AJ, Nieuwland G, van Duyl FC, Bak RPM (1995) Effects of grazing, sedimentation and phytoplankton cell lysis on the structure of a coastal pelagic food web. Mar Ecol Prog Ser 123:259-271

Cadée GC. Hegeman J (1986) Seasonal and annual variation in Phaeocystss pouchetii (Haptophyceae) in the westernmost inlet of the Wadden Sea during the 1973 to 1985 period. Neth J Sea Res 20(1):29-36

Caron DA. Coldman JC, Dennett MR (1988) Experimental demonstration of the roles of bacteria and bacterivorous protozoa in plankton nutrient cycles. Hydrobiologia 159: $27-40$

Davies ACi, Madariaga I de, Bautista B, Fernández E (1992) The ecology of a coastal Phaeocystis bloom in the north- 
western English Channel in 1990. J Mar Biol Ass UK 72: $691-708$

Egge JK, Aksnes DL (1992) Silicate as regulating nutrient in phytoplankton competition. Mar Ecol Prog Ser 83:281-289

Fenchel T (1982) Ecology of heterotrophic microflagellates IV Quantitative occurrence and importance as bacterial consumers. Mar Ecol Prog Ser 9:35-42

Hansen PJ (1992) Prey size selection, feeding rates and growth dynamics of heterotrophic dinoflagellates with special emphasis on Gyrodinium spirale. Mar Biol 114 $327-334$

Hinga KR (1992) Co-occurrence of dinoflagellate blooms and high $\mathrm{pH}$ in marine enclosures. Mar Ecol Prog Ser 86 $181-187$

Holligan PM, Harris RP, Newell RC, Harbour DS, Head RN Linley EAS, Lucas MI, Tranter PRG, Weekley CM (1984) Vertical distribution and partitioning of organic carbon in mixed, frontal and stratified waters of the English Channel. Mar Ecol Prog Ser 14:111-127

Ikeda $\Upsilon$ (1977) The effects of laboratory conditions on the extrapolation of experimental measurements to the ecology of marine zooplankton. IV. Changes in respiration and excretion rates of boreal zooplankton species maintained under ied and starved conditions. Mar Biol 41:241-252

Jumars PA, Penry DL, Baross JA, Perry MJ, Frost BW (1989] Closing the microbial loop: dissolved carbon pathway to heterotrophic bacteria from incomplete ingestion, digestion and absorption in animals. Deep Sea Res 36(4):483-495

Jürgens K, Güde H (1990) Incorporation and release of phosphorus by planktonic bacteria and phagotrophic flagellates. Mar Ecol Prog Ser 59:271-284

Klein Breteler WCM, Fransz HG, Gonzalez SR (1982) Growth and development of four calanoid copepod species under experimental and natural conditions. Neth J Sea Res 16 : $195-207$

Lancelot C (1995) The mucilage phenomenon in the cont1nental coastal waters of the North Sea. Sci Total Environ 165:83-102

Lancelot C, Billen G. Barth H (1991) The dynamics of Phaeocystis blooms in nutrient enriched coastal zones. Water Pollution Research Report Series of the Environmental Research and Development Programme of the Commission of the European Communities, Belgium (Ref no 23)

Lancelot C, Billen G, Sournia A, Weisse T, Colijn F, Veldhuis MJW, Davies A, Wassmann P (1987) Phaeocystis blooms and nutrient enrichment in the continental coastal zones at the North Sea. Ambio 16(1):38-47

Lancelot C, Mathot S, Owens N.JP (1986) Modelling protein synthesis, a step to an accurate estimate of net primary production: Phaeocystis pouchetii colonies in Belgian coastal waters. Mar Ecol Prog Ser 32:193-202

Lignell R, Heiskanen AS, Kuosa H, Gundersen K, KuuppoLeinikki P, Pajuniemi R, Uitto A (1993) Fate of a phytoplankton spring bloom, sedimentation and carbon flow in the planktonic food web in the northern Baltic. Mar Ecol Prog Ser 94:239-252

Lubbers GW, Gieskes WWC, del Castillo P, Salomons W, Bril $J$ (1990) Manganese accumulation in the high pH microenvironment of Phaeocystis sp. (Haptophyceae) colonies from the North Sea. Mar Ecol Prog Ser 59:285-293

McCarthy JJ, Taylor WR, Taft JL (1975) The dynamics of nitrogen and phosphorus cycling in the open waters of the Chesapeake Bay. In: Church TM (ed) Marine chemistry In the coastal environment. ACS Symposium Series 18, American Chemical Society, Washington, DC

Moloney CL, Bergh MO, Field JG, Newell RC (1986) The effect of sedimentation and microbial nitrogen regeneration in a plankton community: a simulation investigation. J Plankton Res 8(3):427-445

Parsons TR, Harrison PJ, Waters R (1978) An experimental simulation of changes in diatom and flagellate blooms. $J$ Exp Mar Biol Ecol 32:285-294

Passow U (1991) Species-specific sedumentation and sinking velocities of diatoms. Mar Biol 108:449-455

Pennock JR (1985) Chlorophyll distribution in the Delaware Estuary: regulation by light-limitation. Estuar Coast Shelf Sci 21:711-725

Peperzak L (1993) Daily irradiance governs growth rate and colony formation of Phaeocystis (Prymnesiophyceae). J Plankton Res 15(7):809-821

Pomeroy LR, Wiebe WJ (1993) Energy sources for microbial food webs. Mar Microb Food Webs 7(1):101-118

Pomeroy LR, Wiebe WJ, Deibel D, Thompson RJ, Rowe GT, Pakulski JD (1991) Bacterial responses to temperature and substrate concentration during the Newfoundland spring bloom. Mar Ecol Prog Ser 75:143-159

Proctor LM, Okubo A, Fuhrman JA (1993) Calibrating estimates of phage-induced mortality in marine bacteria: ultrastructural studies of marine bacterinphage dovolopment from one-step growth experiments. Microb Ecol 25: 161-182

Putt M, Stoecker DK (1989) An experimentally determined carbon:volume ratio for marine 'oligotrichous' ciliates form estuarine and coastal waters. Limnol Oceanogr 34(6): $1097-1103$

Rassoulzadegan F, Laval-Peuto M, Sheldon RW (1988) Partitioning of the food ration of marine ciliates between picoand nanoplankton. Hydrobiologia 159:75-88

Rhee GY, Gotham IJ (1981a) The effect of environmental factors on phytoplankton growth: temperature and the interactions of temperature with nutrient limitation. Limnol Oceanogr 26(4):635-648

Rhee GY, Gotham IJ (1981 b) The effect of environmental factors on phytoplankton growth: light and the interactions of light with nitrate limitation. Limnol Oceanogr 26(4): $649-659$

Riebesell U (1989) Comparison of sinking and sedimentation rate measurements in a diatom winter/spring bloom. Mar Ecol Prog Ser 54:109-119

Riebesell U, Wolf-Gladrow DA, Smetacek V (1993) Carbon dioxide limitation of marine phytoplankton growth rates. Nature 361:249-251

Riegman R, Kuipers BR, Noordeloos AAM, Witte HJ (1993) Size-differential control of phytoplankton and the structure of plankton communities. Neth J Sea Res 31(3): 255-265

Riegman R, Noordeloos AAM, Cadée GC (1992) Phaeocystis blooms and eutrophication of the continental coastal zones of the North Sea. Mar Biol 112:479-484

Schaumann K, Gerdes D. Hesse KJ (1988) Hydrographic and biological characteristics of a Noctiluca scintillans red tide in the German Bight, 1984. Meeresforschung 32:77-91

Simon M, Azam F (1989) Protein content and protein syntheses rates of planktonic bacteria. Mar Ecol Prog Ser 51 $201-213$

Syrett PJ (1981) Nitrogen metabolism of microalgae. Can Bull Fish Aquat Sci 210:182-210

Thingstad F, Billen G (1994) Microbial degradation of Phaeocystis material in the water column J Mar Syst 5:55-65

Van Boekel WHM, Hansen FC, Riegman R, Bak RPM (1992) Lysis-induced decline of a Phaeocystis spring bloom and coupling with the microbial foodweb. Mar Ecol Prog Ser 81:269-276 
Verity PG (1985) Grazing, respiration, excretion, and growth rates of tintinnids. Limnol Oceanogr 30(6):1268-1282

Verity PG (1986) Growth rates of natural tintinnid populations in Narragansett Bay. Mar Ecol Prog Ser 29:117-126

Verity PG, Villareal TA, Smayda TJ (1988) Ecological investigations of blooms of colonial Phaeocystis pouchetii. II. The role of life-cycle phenomena in bloom termination J Plankton Res 10(4):749-766

Wassmann P (1994) Significance of sedimentation for the ter-

This article was submitted to the editor mination of Phaeocystis blooms. J Mar Syst 5:81-100 Weisse $T$ (1990) Trophic interactions among heterotrophic microplankton, nanoplankton, and bacteria in Lake Constance. Hydrobiologia 191:111-122

Yoder JA (1979) A comparison between the cell division rate of natural populations of the marine diatom Skeletonema costatum (Greville) Cleve grown in dialysis culture and that predicted from a mathematical model. Limnol Oceanogr 24(1):97-106

Manuscript first received: May 6, 1996

Revised version accepted: September 27, 1996 